Article

\title{
Evaluation of Filamentous Fungi and Yeasts for the Biodegradation of Sugarcane Distillery Wastewater
}

\author{
Graziella Chuppa-Tostain ${ }^{1}$, Melissa Tan ${ }^{2,3}$, Laetitia Adelard ${ }^{4}$, Alain Shum-Cheong-Sing ${ }^{2}$, \\ Jean-Marie François 5 (D), Yanis Caro 2,3 () and Thomas Petit $2,3, * \mathbb{C}$ \\ 1 Competitiveness Cluster Qualitropic, 5 rue André Lardy, 97438 Sainte-Marie, Réunion Island, France; \\ graziella.tostain@qualitropic.fr \\ 2 Laboratoire de Chimie et Biotechnologies des Produits Naturels, Université de la Réunion, \\ CHEMBIOPRO (EA 2212), 15 Avenue René Cassin, 97490 Sainte Clotilde, Réunion Island, France; \\ melissa.tan@univ-reunion.fr (M.T.); alain.shum@univ-reunion.fr (A.S.-C.-S.); \\ yanis.caro@univ-reunion.fr (Y.C.) \\ 3 Département HSE, IUT de la Réunion, 40 Avenue de Soweto Terre-Sainte, BP 373, 97455 Saint-Pierre CEDEX, \\ Réunion Island, France \\ 4 Laboratoire de Physique et Ingénierie Mathématique pour l'Energie et l'EnvironnemeNT (PIMENT), \\ Université de la Réunion, 117 rue Général Ailleret, 97430 Le Tampon, Réunion Island, France; \\ laetitia.adelard@univ-reunion.fr \\ 5 Laboratoire d'Ingénierie des Systèmes Biologiques et des Procédés, INSA de Toulouse, UMR INSA/CNRS \\ 5504-UMR INSA/INRA 792, 135 Avenue de Rangueil, CEDEX 4, 31077 Toulouse, France; \\ fran_jm@insa-toulouse.fr \\ * Correspondence: thomas.petit@univ-reunion.fr; Tel.: +33-262-692-65-1148
}

Received: 20 September 2020; Accepted: 4 October 2020; Published: 15 October 2020

check for updates

\begin{abstract}
Sugarcane Distillery Spent Wash (DSW) is among the most pollutant industrial effluents, generally characterized by high Chemical Oxygen Demand (COD), high mineral matters and acidic $\mathrm{pH}$, causing strong environmental impacts. Bioremediation is considered to be a good and cheap alternative to DSW treatment. In this study, 37 strains of yeasts and filamentous fungi were performed to assess their potential to significantly reduce four parameters characterizing the organic load of vinasses (COD, $\mathrm{pH}$, minerals and $\mathrm{OD}_{475 \mathrm{~nm}}$ ). In all cases, a $\mathrm{pH}$ increase (until a final $\mathrm{pH}$ higher than 8.5, being an increase superior to 3.5 units, as compared to initial $\mathrm{pH}$ ) and a COD and minerals removal could be observed, respectively (until $76.53 \%$ using Aspergillus terreus var. africanus and $77.57 \%$ using Aspergillus niger). Depending on the microorganism, the $\mathrm{OD}_{475 \mathrm{~nm}}$ could decrease (generally when filamentous fungi were used) or increase (generally when yeasts were used). Among the strains tested, the species from Aspergillus and Trametes genus offered the best results in the depollution of DSW. Concomitant with the pollutant load removal, fungal biomass, with yields exceeding $20 \mathrm{~g} \cdot \mathrm{L}^{-1}$, was produced.
\end{abstract}

Keywords: sugarcane; distillery waste water; molasses spent wash; vinasse; fungi; yeasts; bioremediation; COD; discoloration

\section{Introduction}

In 2012, 83 billion liters of ethanol was produced worldwide, from which a third was from Brazil [1,2]. The European directive 2009/28/CE, relating to the promotion of the use of energy from renewable resources, also called RED (Renewable Energy Directive), sets, for each Member State, a binding target of a 10\% share of renewable energy in the transport field in 2020. Biofuels production from waste, residues, non-food cellulosic material and lignocellulosic origin is particularly incited [3]. 
In Reunion Island, the sugarcane industry is one of the most important agricultural and economic activities of the French oversea department, and is located in the Indian Ocean [4].

In 2011, the three rum distilleries still active on the island produced 106,430 Hectoliters of Pure Alcohol (HPA) from sugarcane fermentation and molasses distillation [5]. The rum production is accompanied by the generation of a stillage called vinasse or distillery spent wash (DSW). Owing to the nature of the process, DSW are effluents with a high pollutant load, meaning high Chemical Oxygen Demand (COD, generally in the range of 100 to $150 \mathrm{~g} \mathrm{O}_{2} \mathrm{~L}^{-1}$ ), a low $\mathrm{pH}$ (between 4.5 and 5.5) and a high optical density [6-8]. DSW also generally contains a high amount of potential nutrients such as nitrogen, phosphorous, potassium, sulfur and a large amount of micronutrients like calcium or magnesium [8]. Moreover, it is characterized by a dark brown color due to the presence of colored molecules such as phenolic acids, caramels from overheated sugars and furfurals from acid hydrolysis and melanoidins [9-11].

Melanoidins are dark brown polymers of low and high molecular weights that result from the Maillard reaction. This reaction, which happens at high temperatures and low $\mathrm{pH}$, is a non-enzymatic browning reaction that results from condensation between reducing sugars and amino compounds [12], leading to molecules with complex structures [13]. It has been shown that less than $10 \%$ of the melanoidins present in the stillage can be degraded through conventional anaerobic-aerobic treatments [7,14]. Godshall (1999) showed that the amount of phenolic acids is higher in cane molasses stillage in comparison to beet molasses [15]. Depending on the sugarcane nature and the industrial processes used, intrinsic composition of DSW can vary significantly. Indeed, recent studies concerning COD show that vinasses from Indian and Mexican distilleries have COD around 104 and $121 \mathrm{~g} \mathrm{O}_{2} \mathrm{~L}^{-1}$, respectively, whereas the COD of vinasses from Brazilian distilleries are two and three times less, i.e., $42 \mathrm{~g} \mathrm{O}_{2} \mathrm{~L}^{-1}$. Moreover, proportions of potassium contained in DSW can range from 2.3 to $8.77 \mathrm{~g} \cdot \mathrm{L}^{-1}[16-19]$. These characteristics make DSWs hazardous compounds when, for example, they are discharged in natural waterways. DSW can cause significant environmental problems by reducing the oxygenation of the water, causing eutrophication of contaminated waterways and creating toxic effects on aquatic organisms. Due to the presence of putrescible organics like skatole, indole and other sulfur compounds, DSW produces an obnoxious smell [20]. European and French regulations describe the strict specifications for industrial effluents. Their COD value must be less than $125 \mathrm{mg} \mathrm{O}_{2} \mathrm{~L}^{-1}[21]$.

Among the different ways of treatment, bioremediation offers a good perspective as it constitutes a cheaper and easier technique compared to physico-chemical technologies. Different types of microorganisms can be used for bioremediation, namely bacteria, microalgae, yeasts or filamentous fungi $[7,8,22]$. Due to their rapid growth, yeasts are widely used in DSW treatment. Among the 203 yeast strains tested, Akaki and collaborators showed that strains from Hansenula, Debaryomyces and Rhodotorula genus could remove a range of $32-38 \%$ of COD contained in a diluted and supplemented DSW medium [23]. Unlike yeasts, filamentous fungi have slower growth but their broad extracellular hydrolytic enzymes allow for the assimilation of complex carbohydrates without prior hydrolysis by another technique. Moreover, they are less sensitive to nutrients, aeration, temperature and $\mathrm{pH}$ variations [24]. In their study, Sirianuntapiboon and collaborators described the potential of 228 fungal strains to discolor molasses. Among them, nine strains, including four species from Aspergillus genus, a strain of Trametes versicolor and four other unidentified strains, showed discoloration yields above $50 \%[25,26]$.

A literature review indicated that species of filamentous fungi such as Penicillium, Aspergillus (A. niger, A. oryzae and A. terreus), Galactomyces geotrichum, Trametes versicolor, Phanerochaete chrysosporium and Flavodon flavus and the yeasts Candida tropicalis, P. jadinii and Issatchenkia orientalis had already been highlighted because of their ability to remove refractory compounds from distillery wastewater $[7,8,20,27-36]$. However, most of these strains were tested in different and heterogeneous conditions and not all on vinasse from sugarcane distilleries. In this study, we report a comprehensive and standardized screening program, including 37 strains of yeasts and filamentous 
fungi selected from the abovementioned literature and from our own selection (provided from laboratory fungal strain collections) for their ability to degrade complex compounds of DSW from sugarcane. The capacity of each strain to grow and metabolize the substrates contained in vinasse was evaluated by following the evolution of a number of physicochemical parameters such as $\mathrm{pH}, \mathrm{COD}$, mineral matter, optical density and microbial biomass production.

\section{Materials and Methods}

\subsection{Biological Material and Growth Conditions}

Sugarcane Distillery Spent Wash (DSW) was collected directly at the column outlet (between $85^{\circ} \mathrm{C}$ and $100^{\circ} \mathrm{C}$ ) from "Rivière du Mât" sugarcane distillery, Saint-Benoit, Reunion Island. After cooling, DSW was stored in small sterile bags at $-20^{\circ} \mathrm{C}$ until used. The yeasts and filamentous fungi strains used in this study were purchased from BCCM (Brussels, Belgium) strain collections (Table 1). The 37 selected strains used in this study were chosen according to their specific properties to degrade complex molecules and particularly DSW.

In order to be able to measure the depollution potential of the strains, independently of their capacity to grow on this medium, we decided to uncouple the depollution ability of the strain and the biomass production. Pre-cultures were therefore prepared by inoculating a full loop of $48 \mathrm{~h}$ growing cells on basal agar plate (PDA-Potatoes Dextrose Agar from Biotop) in sterile Malt Agar broth (MA-Merck, Germany) and incubated for $72 \mathrm{~h}$. At the end of the incubation in MA broth, the total biomass formed was aseptically harvested by centrifugation, washed twice in sterile milliQ water and used for the inoculation of the main cultures. The main culture experiments contained $50 \mathrm{~mL}$ of autoclaved DSW $\left(121^{\circ} \mathrm{C}, 20 \mathrm{~min}\right)$. Yeast and filamentous fungi biomass harvested from pre-cultures were inoculated at a concentration of $10^{5}$ cells (yeasts) or spores (filamentous fungi) per $\mathrm{mL}$ in the main culture flasks and incubated under aerobic conditions at $110 \mathrm{rpm}$ and $25^{\circ} \mathrm{C}$ for 10 days. Biomass and culture broth were then separated by filtration (filamentous fungi) or centrifugation (yeasts). Filtrations were performed on a Buchner system using Whatman filter No. 1. All centrifugations were carried out for $15 \mathrm{~min}$ at $8500 \mathrm{rpm}$.

\subsection{Physico-Chemical Analysis}

Cells harvested by centrifugation or filtration were incubated for $24 \mathrm{~h}$ at $105{ }^{\circ} \mathrm{C}$ for biomass determination. Supernatants and filtrates were stored at $-20{ }^{\circ} \mathrm{C}$ before being used. The $\mathrm{pH}$ of broth medium during fermentation was measured using a pH-meter Denver Instrument (Germany). To evaluate the mineral content, ashes were measured by the incineration of $10 \mathrm{~g}$ of broth medium at $550{ }^{\circ} \mathrm{C}$ for $3 \mathrm{~h}$ in a muffle furnace Nabertherm Controller B170 (Lilienthal, Germany) [37]. COD measurements were carried out using Hanch Lange diagnostic kits (LCK 914) and measured spectrophotometrically with a DR 2800 spectrophotometer (Hach Lange, Dusseldorf, Germany). When necessary, the samples were adequately diluted with sterile deionized water and analyzed according to the manufacturer's instructions.

Absorbance of filtrates or supernatants was measured at $475 \mathrm{~nm}$ (corresponding to melanoidins) using a spectrophotometer Genesys 10 UV Scanning (Waltham, MA, USA) according to [19]. The discoloration yield was calculated according to the following equation:

$$
\text { Discoloration }(\%)=\frac{I-F}{I},
$$

with $I=$ Initial absorbance (Control) and $F=$ Absorbance after aerobic fermentation. All assays were performed in triplicates.

\subsection{Chemometrics}

Multivariate statistics, including Principal Component Analysis (PCA) and Hierarchical Cluster Analysis (HCA), were employed to investigate the relationships among species with similar 
performances concerning biomass production and variations of $\mathrm{pH}$, mineral content, $\mathrm{COD}$ and $\mathrm{OD}_{475 \mathrm{~nm}}$. PCA using Pearson correlation is a statistical method used in order to combine the original parameters (physicochemical variables) into several new uncorrelated components without losing significant information. The aim of this statistical method is to explain the variance-covariance structure of an experimental data set using a new set of coordinate systems. Every new principal component consisted of the linear combination of the original variables [38]. This method enabled us to define the characteristics of specific groups of strains. Hierarchical cluster analysis (HCA) was then used to identify the strains belonging to these groups. HCA is a statistical method to search for homogeneous clusters based on measured parameters. The hierarchical clustering process is represented by a dendrogram, in which each step of the clustering process is illustrated by a connection in the tree. Differences between these classes were tested with average Euclidean distances using the Ward method based on a variance approach. This Ward method provides a simple approach to approximate, for any given number of clusters, the partition minimizing the within-cluster inertia or "error sum of squares". In this study, the method was performed with the aim of minimizing the sum of the squares of any two clusters that could be formed at each step. The clusters were then fused in order to reduce the variability within a cluster. Further, the fusion of two clusters resulted in a minimum increase of the "error sum of squares" [39]. These analyses were performed thanks to XLSTAT programs (Addinsoft, Inc., Paris, France).

\section{Results and Discussion}

\subsection{Effect of Aerobic Treatment on Chemical Oxygen Demand (COD)}

The effect of the treatment of DSW on COD was found to be highly dependent of the strains used for aerobic treatment (Table 1). Aerobic fermentation of DSW by Phanerochaete chrysosporium, Flavodon flavus, Fusarium proliferatum and Gibberella fujikuroi appeared to be less efficient strains for COD reduction, with $23.5 \%, 28 \%, 34 \%$ and $38 \%$, respectively, whereas Aspergillus terreus var africanus, A. parasiticus, Trametes hirsuta, T. versicolor and $A$. terreus var. terreus showed the highest decrease in COD (76.53\%, $74.60 \%, 74.01 \%, 73.64 \%$ and $73.5 \%$, respectively). Notably, the 9 Aspergillus and anamorph strains used in this study were among the most effective strains for COD reduction (COD reduction was higher than $65 \%$ for all 8 Aspergillus strains and $58.65 \%$ for Fennellia flavipes), indicating that these strains are particularly interesting for their reduction of the pollution load of DSW. COD reduction by Pichia jadinii and Penicillium sp. could reach $40.91 \%$ and circa $62 \%$, respectively.

Some of our results were consistent with other published works. For instance, Gonzalez et al. (2000) reported a high COD reduction (62\%) on diluted molasses spent wash treated by Trametes spp. [14]. Benito et al. (1997) also found that T. versicolor was able to reduce COD by more than $70 \%$ on supplemented sugar beet molasses [40]. Similarly, a reduction of $46 \%$ and $65 \%$ of COD was found for P. jadinii and Penicillium sp., respectively [30,41]. Aerobic treatment of cane molasses stillage with $A$. niger and $A$. oryzae led to a COD reduction of up to $78 \%$ and $88 \%$, respectively [31-33]. On the contrary, Garcia et al. (1997) found that $A$. terreus lowered the COD of DSW by only 29\% [34]. Surprisingly, our results using P. chrysosporium and F. flavus were found to be well below the observed values from the literature with, respectively, a 73\% COD reduction on DSW supplemented with yeast extract and $80 \%$ on diluted DSW [42,43]. This difference may be explained by the fact that these studies were carried out on diluted and supplemented DSW, while we used crude DSW in our study. Moreover, COD reduction is generally concomitant with the discoloration of the vinasse. In their study, Fahy and collaborators (1997) showed that a sugar addition in the medium could significantly improve the depollution rate of vinasse by P. chrysosporium [44]. From these results, the efficiency of the strains to reduce COD is strongly dependent of the origin of the vinasse used (beet or cane for example) and their complementation with other sources of nutriments. 
Table 1. Strains used in this study, effects of aerobic treatment of DSW on physicochemical parameters and biomass production.

\begin{tabular}{|c|c|c|c|c|c|c|c|}
\hline $\begin{array}{l}\text { Strain } \\
\text { Number }\end{array}$ & Strains (Genera/Specie) & MUCL Reference Number & Reduction of $\operatorname{COD}^{1}(\%)$ & $\begin{array}{l}\text { Effect on OD at } \\
475 \mathrm{~nm}^{2}(\%)\end{array}$ & $\begin{array}{l}\text { Reduction of Minerals } \\
\text { Content }{ }^{3}(\%)\end{array}$ & Final $\mathrm{pH}^{4}$ & Biomass Production ${ }^{5}\left(\mathrm{~g} \cdot \mathrm{L}^{-1}\right)$ \\
\hline S1 & Arthroderma otae & MUCL 41713 & 59.22 & 98.26 & 36.99 & 6.91 & 18.11 \\
\hline S2 & Aspergillus alutaceus & MUCL 39539 & 69.23 & 58.12 & 73.49 & 7.91 & 21.7 \\
\hline S3 & Aspergillus flavus & MUCL 19006 & 70.86 & 80.00 & 20.88 & 8.72 & 19.77 \\
\hline S4 & Aspergillus itaconicus & MUCL 31306 & 73.23 & 64.64 & 40.94 & 7.64 & 21.41 \\
\hline S5 & Aspergillus niger & MUCL 19001 & 70.11 & 73.04 & 77.57 & 8.31 & 21.25 \\
\hline S6 & Aspergillus oryzae & MUCL 19009 & 65.98 & 77.97 & 66.62 & 8.86 & 24.35 \\
\hline S7 & Aspergillus parasiticus & MUCL 14491 & 74.6 & 57.54 & 53.66 & 8.46 & 24.48 \\
\hline $\mathrm{S} 8$ & Aspergillus terreus var africanus & MUCL 38960 & 76.53 & 110.14 & 66,00 & 9,00 & 29.19 \\
\hline S9 & Aspergillus terreus var terreus & MUCL 38640 & 73.5 & 61.16 & 72.4 & 9.05 & 24.90 \\
\hline $\mathrm{S} 10$ & Candida albicans & MUCL 30114 & 56.56 & 118.01 & 29.3 & 8.69 & 19.34 \\
\hline S11 & Candida dubliniensis & MUCL 41201 & 45.98 & 152.53 & 32.18 & 8.45 & 10.29 \\
\hline S12 & Candida glabatra & MUCL 29833 & 57.34 & 130.64 & 26.62 & 8.12 & 12.43 \\
\hline $\mathrm{S} 13$ & Candida tropicalis & MUCL 29893 & 50.41 & 138.72 & 20.75 & 8.42 & 15.21 \\
\hline S14 & Clavispora lusitanea & MUCL 29855 & 54.72 & 116.84 & 28.35 & 7.39 & 28.56 \\
\hline S15 & Colletotricum graminicola & MUCL 44764 & 57.75 & 92.17 & 39.23 & 7.94 & 11.79 \\
\hline S16 & Cryptococcus albidus & MUCL 30400 & 44.89 & 135.35 & 30.29 & 8.13 & 12.47 \\
\hline S17 & Fennellia flavipes & MUCL 38811 & 58.65 & 75.65 & 61.46 & 8.74 & 17.98 \\
\hline S18 & Flavodon flavus & MUCL 38427 & 28.99 & 77.10 & 37.48 & 6.17 & 14.98 \\
\hline S19 & Fusarium proliferatum & MUCL 43482 & 34.44 & 91.59 & 53.83 & 6.37 & 6.38 \\
\hline S20 & Fusarium sporotrichioides & MUCL 6133 & 55.13 & 140.00 & 43.81 & 8.25 & 8.6 \\
\hline $\mathrm{S} 21$ & Galactomyces geotrichum & MUCL 43077 & 56.95 & 104.64 & 46.39 & 8.26 & 6.79 \\
\hline $\mathrm{S} 22$ & Gibberella fujikuroi & MUCL 42883 & 37.89 & 106.96 & 36.58 & 6.76 & 4.12 \\
\hline S24 & Issatchenkia orientalis & MUCL 29849 & 48.13 & 139.73 & 49.56 & 8.08 & 25.41 \\
\hline S25 & Komagatella pastoris & MUCL 31260 & 69.7 & 107.41 & 56.84 & 7.99 & 9.1 \\
\hline S26 & Penicillium rugulosum & MUCL 41583 & 62.48 & 86.38 & 56.28 & 8.72 & 2.36 \\
\hline S27 & Penicillium verrucosum & MUCL 28674 & 62.09 & 168.99 & 49.05 & 9.03 & 8 \\
\hline S28 & Phanerochaete chrysosporium & MUCL 38489 & 23.51 & 74.20 & 70.49 & 7.01 & 17 \\
\hline S29 & Pichia angusta & MUCL 27761 & 49.52 & 114.14 & 20.78 & 6.53 & 4.04 \\
\hline S30 & Pichia guilliermondii & MUCL 29837 & 54.78 & 138.38 & 28.21 & 7.54 & 12.23 \\
\hline S31 & Pichia jadinii & MUCL 30058 & 40.91 & 141.08 & 46.33 & 8.21 & 14.67 \\
\hline $\mathrm{S} 32$ & Pseudozyma antarctica & MUCL 47637 & 51.33 & 136.03 & 22.11 & 8.9 & 0.75 \\
\hline S33 & Rhizopus microsporus var oligosporus & MUCL 31005 & 67.32 & 95.94 & 52.04 & 8.85 & 14.66 \\
\hline S34 & Saccharomyces cerevisiae & MUCL 39449 & 55.84 & 190.91 & 41.17 & 8.88 & 11.64 \\
\hline S35 & Thanatephorus cucumeris & MUCL 43254 & 65.28 & 105.22 & 44.63 & 6.66 & 16.32 \\
\hline S36 & Trametes hirsuta & MUCL 40169 & 74.01 & 57.54 & 62.86 & 7.8 & 29.4 \\
\hline S37 & Trametes versicolor & MUCL 44890 & 73.64 & 67.54 & 39.05 & 7.79 & 25.96 \\
\hline
\end{tabular}

${ }^{1}$ Reduction of COD corresponded to ratio between COD removal during aerobic fermentation and initial COD of crude DSW based upon $100 \%$; ${ }^{2}$ Evolution of OD measured at $475 \mathrm{~nm}$

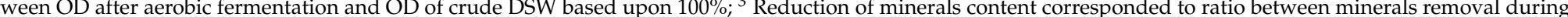
aerobic fermentation and initial minerals content of crude DSW based upon $100 \% ;{ }^{4}$ Final pH measured in DSW broth after 10 days of fermentation; ${ }^{5}$ Biomass production was determined according to Materials and Methods (Sections 2.1 and 2.2) and corresponded to the difference between biomass obtained after DSW filtration at the end of 10 days fermentation and biomass inoculated on DSW at the beginning of the fermentation. Biomass inoculated was the sum between fungal cells obtained after growth on MA broth and total solids content naturally contained on DSW. 


\subsection{Effect of Aerobic Treatment on Colour}

The effect of aerobic treatment of DSW on color was studied using optical density of DSW supernatant at $475 \mathrm{~nm}$ [19]. Consistent with the COD reduction, we found that the strains showing the highest reduction of color belong to Aspergillus and Trametes genus (Table 1). For instance, Aspergillus parasiticus, A. alucateus, A. terreus var. terreus and A. itaconicus led to a decrease of $\mathrm{OD}_{475} \mathrm{~nm}$ up to $42.46 \%$, $41.88 \%, 38.84 \%$ and $35.36 \%$, respectively (Table 1). Similarly Trametes hirsuta and T. versicolor reached up to 42.46 and $32.46 \%$ of decolourisation of DSW. DSW treatment with A. flavus, A. niger, A. oryzae, Fenellia flavipes, Flavodon flavus and Phanerochaete chrysosporium also led to decolourization of DSW but to a lesser extent $\left(\mathrm{OD}_{475 \mathrm{~nm}}\right.$ reduction was comprised of between 20 and 27\%). Surprisingly, we observed that aerobic treatment of DSW by the yeasts (belonging to Candida, Clavispora, Cryptococcus, Galactomyces, Issatchenkia, Komagatella, Pichia and Saccharomyces genus) and by Fusarium sporotrichoides and Penicillium verrucosum resulted in small to high increase of $\mathrm{OD}_{475 \mathrm{~nm}}$. The most important increases of colourization were obtained for Saccharomyces cerevisiae (90.91\%), P. verrucosum (68.99\%), C. dubliniensis (52.53\%), P. jadinii (41.08\%), F. sporotrichoides (40\%), Issatchenkia orientalis (39.73\%), C. tropicalis (38.72\%), P. guilliermondii (38.38\%), Pseudozyma antarctica (36.03\%), Cryptococcus albidus (35.35\%) and C. glabrata (30.64\%). The other yeasts species (C. albicans, P. angusta, Komagatella pastoris, Galactomyces geotrichum, Rhizopus microsporus. var oligosporus and Thanatephorus cucumeris) showed only limited colorization of the broth (less than 18\%). A study has already noticed the increase of color after treatment. Kumar and collaborators (1998) reported that the optimum discoloration was closely related to the optimal growth and that the overall discoloration was obtained in the $\mathrm{pH}$ range of between five and eight, whereas at extreme $\mathrm{pH}$ levels, an increase in color was observed [42]. We can then hypothesize that the coloration observed in this study is probably due to the high final $\mathrm{pH}$ reached at the end of the process (Table 1). Finally, Kumar and collaborators (1998) reported that optimal discoloration was closely related to optimal growth and that overall discoloration was obtained in the $\mathrm{pH}$ range of five to eight, while at extreme $\mathrm{pH}$ levels, an increase in color was observed [42].

With respect to the color of DSW treated with A. niger, F. flavus, T. versicolor and P. chrysosporium, our results showed a lower impact, as compared to the literature. One of the most studied fungi for potential decolourization of distillery effluent was Aspergillus sps. Aspergillus fumigatus G-2-6, Aspergillus niger, A. niveus, A. fumigatus UB260 had an average of 55-79\% decolourization [45-50]. Miranda et al. (1996) showed that, under optimal nutrient concentrations, aerobic treatment using $A$. niger allowed for a decolourization of beet molasses by $69 \%$. Furthermore, they reported that $83 \%$ of the total color removed was eliminated biologically and $17 \%$ by adsorption on the mycelium [47]. Under optimal $\mathrm{pH}$, Patil and collaborators (2003) showed that a melanoidin solution was decolourized from $60 \%$ to $72 \%$ by A. niger immobilized cells [51]. Raghukumar et al. (2001) reported that a diluted cane molasses stillage treated with F. flavus could reach up to $80 \%$ decolourization [43]. Further, aerobic treatment of a diluted molasses spent wash by $T$. versicolor had a decolourization yield of $53 \%$ [52]. When beet molasses were used, the decolourization yielded $58-81 \% \mathrm{OD}_{475 \mathrm{~nm}}$ reduction. From 53.5 to $80 \%$ of decolourization of supplemented molasses spent wash treated by P. chrysosporium was reported [40,42]. Moreover, Fahy and coworkers (1997) demonstrated that the further addition of a carbon source like glucose in a $6.25 \%$ molasses spent wash medium strongly enhanced the decolourization yield from 49 to $80 \%$ by P. chrysosporium [44].

Some of our results were somewhat contradictory with other published works. For instance, a study showed that $C$. tropicalis could reach $75 \%$ decolourization level of a supplemented molasses spent wash when incubated at $45{ }^{\circ} \mathrm{C}$ [19]. Likewise, treatment of distillery spent wash with the ascomycetes of Penicillium genus resulted in about 50\% reduction of the color [46]. With reference to Thanatephorus cucumeris (Rhizoctonia sp. D-90), Sirianuntapiboon and coworkers (1995) reported the decolourization of a melanoidin medium (molasses) by $87.5 \%$ thanks to an absorption mechanism. Indeed, the pigments were accumulated in cytoplasm and around the cell membrane before their degradation by intracellular enzymes [53]. To the best of our knowledge, no studies have focused on the decolourization of DSW by Galactomyces geotrichum, Rhizopus microsporus, Giberella fujikuroi and 
Fusarium sp. Notwithstanding this, considering their use for molasses decolourization, Galactomyces geotrichum and Rhizopus microsporus var. oligosporus could achieve a color reduction of diluted molasses of up to $87 \%$ and 38\%, respectively [36]. Similarly, Seyis and Subasioglu (2009) showed that molasses decolourization by Gibberella fujikuroi and Fusarium species were not successful [54]. The $\mathrm{OD}_{475} \mathrm{~nm}$ increase could result from pigments repolymerization, from a higher rate of nutriment consumption and from production by the microorganism of molecules that also absorb at this wavelength [55-57].

\subsection{Effect of Aerobic Treatment on $\mathrm{pH}$}

Compared to the initial pH of the DSW broth (in the range of 4.77-4.95), all microbial treatments of crude DSW led to a significant increase of final pH (Table 1). Alkalinisation of the medium may be the result of an ammonium release during the assimilation of nitrogen source like proteins for the microorganism growth or a consumption of organic acids or reducing sugar present in DSW [55]. Among the 37 strains tested in this study, 22 could achieve a $\mathrm{pH}$ final value above 8 units. Among the best alkalinising strains, maximum $\mathrm{pH}$ ( $>9$ units) was reached for DSW incubated with $A$. terreus var. africanus (9.05), P. verrucosum (9.03) and A. terreus var. terreus (9.0). More generally, among the Aspergillus and anamorphs genera, seven strains were found to reach a $\mathrm{pH}$ of above 8.3 units.

Several studies have shown that the degradation of melanoidins, which is related to discoloration, tends to increase with alkaline $\mathrm{pH}$. For instance, Hayase and collaborators (1984) reported that the discoloration of melanoidin occurred more rapidly at alkaline $\mathrm{pH}$ than at acidic or neutral $\mathrm{pH}$ and could reach up to $94 \%$ discoloration at $\mathrm{pH} 10$ [58]. In addition, Mohana and coworkers (2007) reported that melanoidins are less soluble in acidic rather than in alkaline $\mathrm{pHs}$ and that $\mathrm{pHs}$ less than or greater than 7 units lead to a decrease of discoloration activity [59]. Similarly, Agarwal and collaborators (2010) claimed that melanoidins were more soluble at alkaline $\mathrm{pH}$ [60].

Contrary to these studies, we found no specific link between $\mathrm{pH}$ and (dis)colorisation of DSW was shown (see Table 1). Indeed, DSW aerobic fermentations using A. terreus var. terreus and Penicillium verrucosum led, in both cases, to an alkalinisation of the supernatant pH of DSW up to 9 units, but in the first case, an $\mathrm{OD}_{475 \mathrm{~nm}}$ decrease of $38.84 \%$ could be noticed, whereas an $\mathrm{OD}_{475 \mathrm{~nm}}$ increase of $68.99 \%$ was observed in the second case. Likewise, A. oryzae and F. flavus induced a decolourization of DSW by about $22 \%$, but an alkalinisation of $\mathrm{pH}$ of 8.86 and 6.17 , respectively.

As few sugar remain in residues like sugarcane molasses after sugar fabrication, the ethanol production from these residues conduced the use of harsher processing steps to depolymerize the structural polysaccharides. These processes result in side reaction products and in the acidification of the medium that are potentially inhibitory to microbial growth. Therefore, anaerobic digestion of the vinasse produced from sugarcane molasses may be fraught with problems [61]. As aerobic fermentation of DSW by yeasts and filamentous fungi bring about alkalinisation of DSW, the anaerobic digestion of the latter could be improved.

\subsection{Biomass Production and Mineral Content of DSW after Aerobic Treatment}

The biomass production of the 37 yeasts and filamentous fungi strains was measured during growth on crude DSW (Table 1). Microorganisms that presented the best production of biomass during aerobic treatment of DSW were Trametes hirsuta $\left(29.40 \mathrm{~g} \cdot \mathrm{L}^{-1}\right)$, A. terreus var. africanus $\left(29.19 \mathrm{~g} \cdot \mathrm{L}^{-1}\right)$, Clavispora lusitaniae $\left(28.56 \mathrm{~g} \cdot \mathrm{L}^{-1}\right)$, T. versicolor $\left(25.96 \mathrm{~g} \cdot \mathrm{L}^{-1}\right)$ and Issatchenkia orientalis $\left(25.41 \mathrm{~g} \cdot \mathrm{L}^{-1}\right)$. In the same way as $\mathrm{COD}, \mathrm{OD}_{475 \mathrm{~nm}}$ and $\mathrm{pH}$, we again found that the Aspergillus genus was particularly efficient in biomass production on crude DSW. The 9 Aspergillus anamorphs strains showed that biomass productions, after 10 days incubation, were comprised of between $17.98 \mathrm{~g} \cdot \mathrm{L}^{-1}$ (Fennellia flavipes) and $29.19 \mathrm{~g} \cdot \mathrm{L}^{-1}$ (Aspergillus terreus var africanus). Smaller amounts of biomass were observed for aerobic fermentation of crude DSW by the yeasts such as P. jadinii and S. cerevisiae (14.67 and $11.67 \mathrm{~g} \cdot \mathrm{L}^{-1}$, respectively).

Several studies have concluded that the COD reduction and/or decolourisation of diluted and/or supplemented molasses spent wash from sugarcane or sugar beet feedstocks by strains of Aspergillus, 
Penicillium, Candida and Pichia genus was accompanied by a fungal growth on the medium [62]. Biomass productions in DSW treated by Aspergillus and anamorphs strains were somewhat higher than those previously reported in literature. For instance, Rosalem and collaborators (1985) showed that biomass production of Aspergillus niger grown on DSW could vary from 8 to $13 \mathrm{~g} \cdot \mathrm{L}^{-1}$ [32]. Likewise, cellular concentration of Aspergillus oryzae grown on DSW were comprised between 12 and $17 \mathrm{~g} \cdot \mathrm{L}^{-1} \mathrm{dry}$ weight $[31,33]$. In their study, Rolz and collaborators (1975) also demonstrated that biomass production by Penicillium sp. grown on DSW can reach up to $16 \mathrm{~g} \cdot \mathrm{L}^{-1}$ [30].

Data from the literature showed that Issatchenkia orientalis incubated in DSW supplemented with molasses, $\mathrm{MgSO}_{4}$, urea and $\mathrm{H}_{3} \mathrm{PO}_{4}$ could only produce a biomass of up to $8 \mathrm{~g} \cdot \mathrm{L}^{-1}$ [63]. The growth of $S$. cerevisiae on molasses stillage reached a maximum biomass production of about $12.7 \mathrm{~g} \cdot \mathrm{L}^{-1}$ [64]. Similarly, growth of P. jadinii on DSW supplemented on molasses produced from 9 to $18 \mathrm{~g} \cdot \mathrm{L}^{-1}$ of dry biomass [65]. Our results therefore clearly indicate that aerobic treatment of crude DSW by these filamentous fungi and yeast strains could achieve a significant reduction of polluting loads of DSW concomitantly with a high production of dry biomass (Table 1) that could be further valuated into added value molecules. Unexpectedly, our study did not reveal a clear link between biomass production and COD reduction (Table 1). This was particularly true for the strains that grow poorly on DSW (biomass production of P. antarctica, P. rugulosum, P. angusta and G. fujikuroi were comprised between 0.75 and $4.12 \mathrm{~g} \cdot \mathrm{L}^{-1}$ ), but showed a significant decrease in COD ranging from $38 \%$ to $62 \%$. This result indicated that the enzymatic process of the reduction of polluting loads could work independently of the process of using nutriments from DSW for growth.

We also noticed that aerobic treatment by the 37 strains used in this study always resulted in a significant reduction of mineral content of DSW (Table 1). This decrease was considerable after treatment of DSW by F. flavus (61.5\%), A. terreus var. africanus (66\%), A. oryzae $(66.6 \%)$, P. chysosporium $(70.5 \%)$, A. terreus var. terreus $(72.4 \%)$, A. alutaceus $(73.5 \%)$ and A. niger $(77.6 \%)$. In agreement with our results for $\mathrm{COD}, \mathrm{OD}_{475 \mathrm{~nm}}, \mathrm{pH}$ and biomass production, we found that seven out of the nine Aspergillus and anamorphs strains showed a mineral reduction in the broth by at least $50 \%$. This result confirmed the high potential of Aspergillus genus to efficiently reduce the polluting load of DSW concomitantly with a high valuable biomass production. Aerobic treatment conducted with $C$. tropicalis (20.8\%), P. angusta (20.8\%), A. flavus (20.9\%), P. antarctica (22.1\%), C. glabrata (26.6\%), P. guilliermondii $(28.2 \%)$, C. lusitanea $(28.4 \%)$ and C. albicans $(29.3 \%)$ led to a lesser, but significant decrease in mineral content. The growth of microorganisms is strongly dependent on micronutrients (such as iron, copper, manganese, zinc, and nickel) and macronutrients (like potassium, phosphorus, magnesium, nitrogen, sulphur, and calcium). These nutrients are involved in carbohydrate metabolism, amino-acids and vitamins production, Krebs cycle, nucleic acid production, pigments production and enzyme activities $[66,67]$. However, the absence of clear relationship between mineral content and biomass production may suggest that other phenomena are involved in the reduction of minerals in the media. For example, mineral content may decrease from precipitation as a consequence of DSW alkalinisation during aerobic treatment.

\subsection{Statistical Relationships between Physico-Chemical Parameters}

A Principal Component Analysis (PCA) was carried out to group the strains according to their performances on the physico-chemical parameters of DSW (biomass production and variations of $\mathrm{pH}$, minerals content, $\mathrm{COD}$ and $\mathrm{OD}_{475 \mathrm{~nm}}$ ) and we investigated possible correlations between some of them. The Pearson correlation matrix showed that variables were moderately correlated between them (Table 2).

For instance, we detected some correlations for $\mathrm{pH}$ and $\mathrm{COD}$ reduction (with a Pearson correlation coefficient $r$ of 0.508), reduction of minerals content and effect on $\mathrm{OD}_{475 \mathrm{~nm}}(r=0.503)$, biomass production with COD reduction on the one hand $(r=0.466)$ and the effect on $\mathrm{OD}_{475 \mathrm{~nm}}$ on the other hand $(r=0.447)$. Applied to the five original variables, the Cattell's scree diagram [68] highlighted three significant Principal Components (PC) explaining $84.89 \%$ of the total variance, $45.62 \%$ for $\mathrm{PC}_{1}$, 
$26.23 \%$ for $\mathrm{PC}_{2}$ and $13.81 \%$ for $\mathrm{PC}_{3}$ (Appendix $\mathrm{A}-$ Table A1). The active coordinates retained by PCA were used to create Figure $1 \mathrm{~A}, \mathrm{~B}$.

Table 2. Pearson correlation matrix.

\begin{tabular}{cccccc}
\hline Parameters & $\begin{array}{c}\text { Reduction of } \\
\text { COD (\%) }\end{array}$ & $\begin{array}{c}\text { Effect on OD } \\
\text { at } \mathbf{4 7 5} \mathbf{~ n m ~ ( \% ) ~}\end{array}$ & $\begin{array}{c}\text { Reduction of } \\
\text { Minerals Content (\%) }\end{array}$ & Final pH & $\begin{array}{c}\text { Biomass Production } \\
\left(\mathrm{g} \cdot \mathrm{L}^{-1}\right)\end{array}$ \\
\hline $\begin{array}{c}\text { Reduction of COD } \\
(\%)\end{array}$ & $\mathbf{1}$ & $\mathbf{0 . 3 4 4}$ & 0.289 & $\mathbf{0 . 5 0 8}$ & $\mathbf{0 . 4 6 6}$ \\
\hline $\begin{array}{c}\text { Effect on OD at } 475 \\
\text { nm (\%) }\end{array}$ & $\mathbf{0 . 3 4 4}$ & $\mathbf{1}$ & $\mathbf{0 . 5 0 3}$ & -0.197 & $\mathbf{0 . 4 4 7}$ \\
\hline $\begin{array}{c}\text { Reduction of } \\
\text { minerals content (\%) }\end{array}$ & 0.289 & $\mathbf{0 . 5 0 3}$ & $\mathbf{1}$ & 0.179 & $\mathbf{0 . 3 5 5}$ \\
\hline Final pH & $\mathbf{0 . 5 0 8}$ & -0.197 & 0.179 & $\mathbf{1}$ & 0.135 \\
\hline $\begin{array}{c}\text { Biomass production } \\
\left(\mathrm{g} \cdot \mathrm{L}^{-1} \text { ) }\right.\end{array}$ & $\mathbf{0 . 4 6 6}$ & $\mathbf{0 . 4 4 7}$ & 0.355 & 0.135 & $\mathbf{1}$ \\
\hline
\end{tabular}

Bold values are significantly different from 0 at a significance level $\alpha=0.05$.

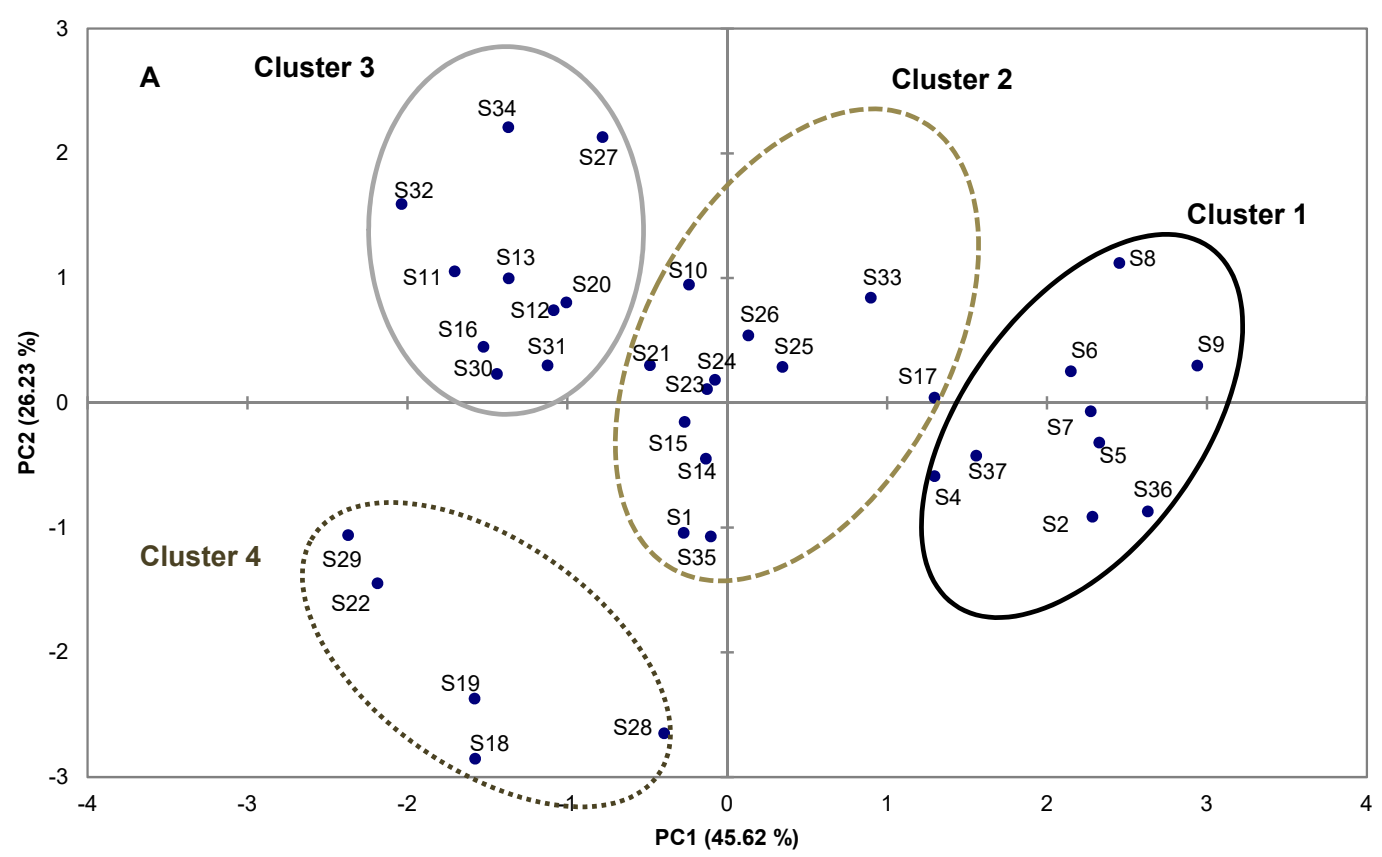

B

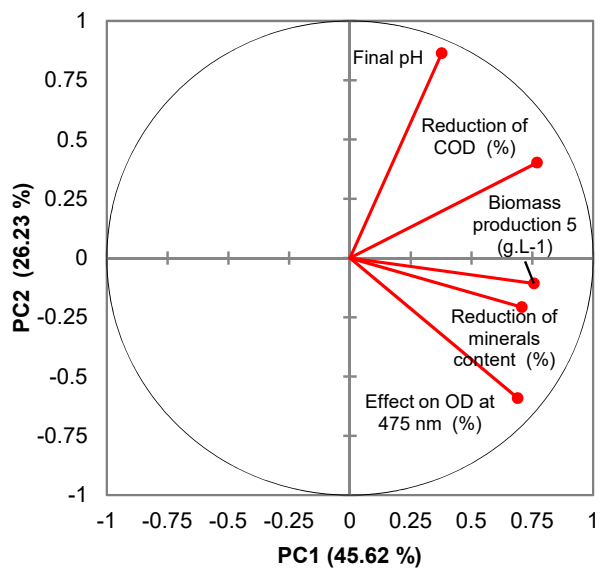

Figure 1. Score plot of $\mathrm{PC}_{2}$ versus $\mathrm{PC}_{1}(\mathbf{A}, \mathbf{B})$ for fungal ability for DSW bioremediation. 
Principal Component Analysis was performed using XLSTAT (Addinsoft). Predicted groups were correlated to CAH clusters. Cluster 1, consisted in strains S2, S3, S4, S5, S6, S7, S8, S9, S36 and S37 which had the most significant COD decreases and biomass production. Cluster 2 includes strains S1, S10, S14, S15, S17, S21, S23, S24, S25, S26, S33 and S35 that had a COD decrease and biomass production yields less higher than ones of the strains of cluster 1. Cluster 3, consisted in strains S11, S12, S13, S16, S20, S27, S30, S31, S32 and S34, which significantly increase $\mathrm{OD}_{475 \mathrm{~nm}}$. The remaining strains (S18, S19, S22, S28 and S29) constituted the last group (Cluster 4) and had a less important effect on the final pH.

The eigenvectors of the covariance calculated enabled the defining of three PCs (Table 3). Only the original variables, whose correlation values with the principal components were greater in absolute value than 0.5 , were taken into account. The first axis $\mathrm{PC}_{1}$ was representative of a global average level of the variables and strongly correlated with four of the five parameters (Appendix A-Table A2). These four parameters (COD reduction, biomass production, minerals content reduction and effect on $\mathrm{OD}_{475 \mathrm{~nm}}$ ) contributed for $93.77 \%$ to $\mathrm{PC}_{1}$ construction. Additionally, the variables (final $\mathrm{pH}$ and the effect on the OD value at $475 \mathrm{~nm}$ ) are in absolute value the original variables best correlated with the $\mathrm{PC} 2$ axis. $\mathrm{PC}_{2}$ axis (Appendix $\mathrm{A}-$ Table $\mathrm{A} 2$ ). It can be noted that $\mathrm{PC}_{2}$ was mainly built by the $\mathrm{pH}$ and the effect on $\mathrm{OD}_{475} \mathrm{~nm}$ variables, i.e., $83.53 \%$ of contribution to $\mathrm{PC}_{2}$ construction. Surprisingly, we found that some fungal species, such as P. antarctica (S32), had very little growth on DSW $\left(0.75 \mathrm{~g} \cdot \mathrm{L}^{-1}\right)$ despite a high COD consumption and a significant increase of $\mathrm{pH}$, while species like P. chrysosporium (S28) showed significant biomass production $\left(17 \mathrm{~g} \cdot \mathrm{L}^{-1}\right)$, concomitant with small $\mathrm{pH}$ increase (7.01) and moderate COD consumption (23\%). Then the third axis $\mathrm{PC}_{3}$ was built mainly on biomass production and minerals content reduction ( $86.56 \%$ of the $\mathrm{PC}_{3}$ construction). The variable reduction of mineral content also greatly contributed to the construction of the $\mathrm{PC}_{3}$ axis (Appendix $\mathrm{A}-\mathrm{Table} \mathrm{A} 2$ ). By opposition to $A$. flavus (S3), which turned out to produce a high amount of biomass $\left(19.77 \mathrm{~g} \cdot \mathrm{L}^{-1}\right)$, but a weak minerals consumption (20.88\%), P. rugulosum (S26) could consume a large amount of mineral content $(56.26 \%)$ with very little growth on DSW $\left(2.36 \mathrm{~g} \cdot \mathrm{L}^{-1}\right)$ (Figure $\left.1 \mathrm{~A}\right)$. These results suggested that a part of the minerals was indeed used for fungal growth, while another part was precipitated due to the alkalinisation of the DSW.

Table 3. Correlations between the parameters and principal components.

\begin{tabular}{cccc}
\hline Parameters & PC1 & PC2 & PC3 \\
\hline Reduction of COD (\%) & 0.769 & 0.402 & -0.234 \\
Effect on OD at 475 nm $(\%)$ & 0.690 & -0.591 & -0.017 \\
Reduction of minerals content $(\%)$ & 0.707 & -0.207 & 0.637 \\
Final pH & 0.377 & 0.864 & 0.195 \\
Biomass production $\left(\mathrm{g} \cdot \mathrm{L}^{-1}\right)$ & 0.756 & -0.107 & -0.439 \\
\hline
\end{tabular}

PCA indicated that the strains could be classified into three to four groups. According to hierarchical cluster analysis (HCA), four groups of strains with close characteristics had been defined, explaining $64.62 \%$ of the total inter-variance and $35.38 \%$ of the total intra-variance (Figure 2 ). The distribution of the clusters according $\mathrm{PC}_{1}$ and $\mathrm{PC}_{2}$ (Figure $1 \mathrm{~A}, \mathrm{~B}$ ) allowed us to define the common characteristics of strains belonging to the same cluster (Appendix A-Table A3). Cluster 1 including the 8 Aspergillus anamorphs strains and the 2 Trametes spp. was characterized by aerobic treatment resulting in both high biomass production, high COD and mineral content reductions and a strong impact on $\mathrm{OD}_{475} \mathrm{~nm}$, resulting in significant decolourization. Cluster 3 included strains that led to a significant increase of $\mathrm{OD}_{475 \mathrm{~nm}}$ that could reach $190.9 \%$ in comparison to the $\mathrm{OD}_{475} \mathrm{~nm}$ of crude DSW and conduced to the lesser mineral consumption. Cluster 4 consisted of strains whose effect on final $\mathrm{pH}$ was less important and that brought to a lesser biomass production and COD reduction. The final $\mathrm{pH}$ of DSW treated by strains defined in Clusters 1 and 3 were generally above $\mathrm{pH}=8$ whereas the $\mathrm{pH}$ of DSW treated by strains of Cluster 4 had a $\mathrm{pH}$ lower than seven. Cluster 2, which gathered all the 
other strains, was formed by strains that influenced COD and mineral contents and produced biomass on DSW, but less significantly than the strains of Cluster 1.

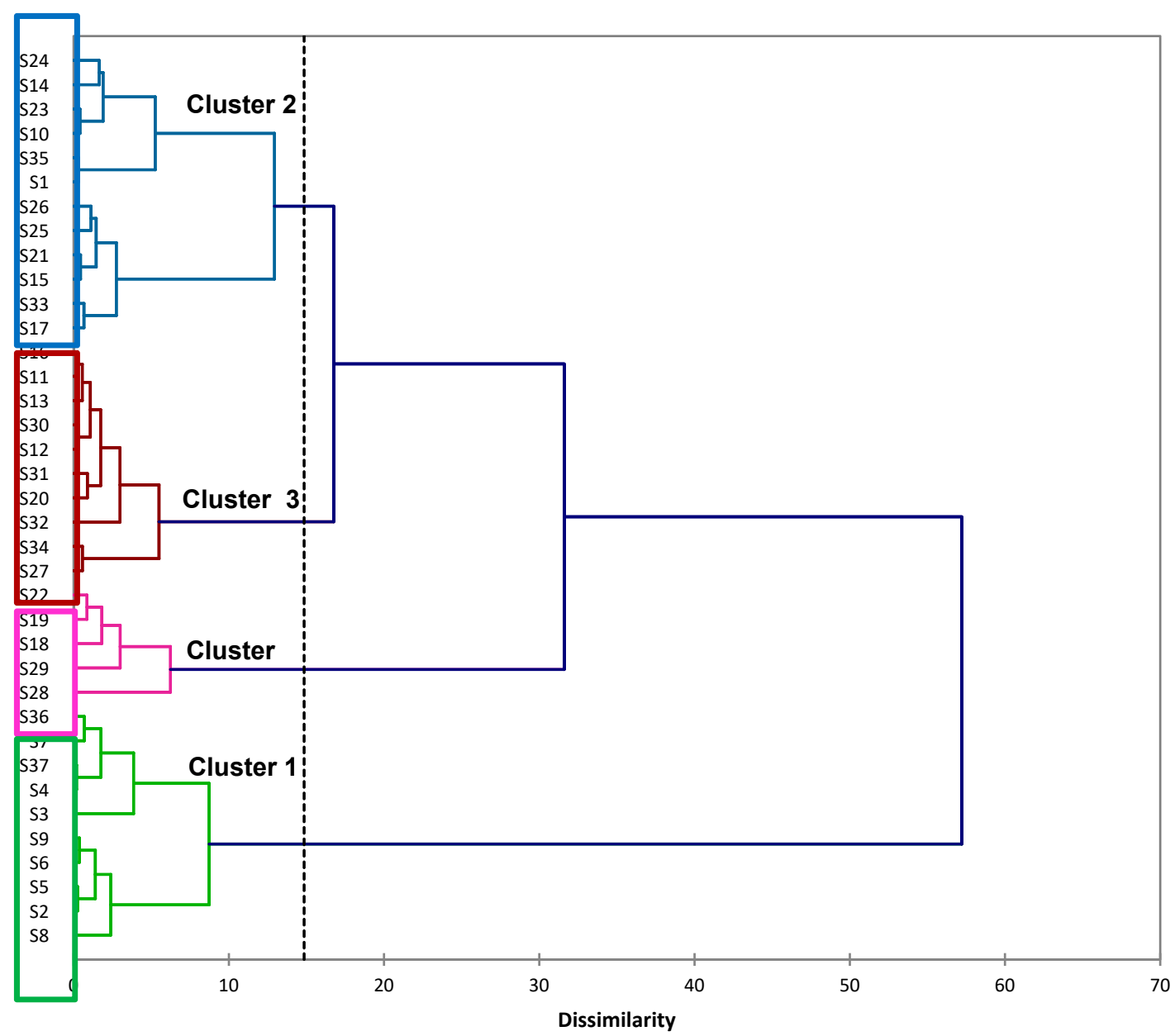

Figure 2. Hierarchical clustering of fungi species using Ward's method and XLSTAT (Addinsoft).

Automatic truncation based on entropy (dotted line) allowed identifying four consistent groups of fungi explaining $64.62 \%$ of the total inter-variance and $35.38 \%$ of the total intra-variance. Order of appearance of clusters (from top to down) was Cluster 2, Cluster 3, Cluster 4 and Cluster 1.

\section{Conclusions}

Among the 37 strains studied, we demonstrated that species from the Aspergillus and Trametes genus generally gave the best results for bioremediation purposes with COD reductions reaching until $77 \%$, decolourization yields until $43 \%$ and a significant alkalizing ability (pH increase of 4 units). While the data from the literature concerned diluted and/or supplemented vinasse, our study first reported the depolluting potential of these same strains on raw vinasse. Mitigation of the pollution potential of aerobically treated effluent compared to crude vinasse was reflected in the significant increase of $\mathrm{pH}$ and high COD and mineral consumptions. Utilization of filamentous fungi and yeasts for sugarcane vinasse treatment turned out to be very promising. Mixed cultures should be performed in order to improve the depollution yields. Moreover, some strains were able to show striking growth on raw DSW. Seven of the nine Aspergillus sp. strains, the white-rot fungi Trametes versicolor and T. hirsuta and two yeasts Clavispora lusitanea and Issatchenkia orientalis could reach biomass yields higher than $20 \mathrm{~g} \cdot \mathrm{L}^{-1}$. The high yields of fungal biomass produced (until $29 \mathrm{~g} \cdot \mathrm{L}^{-1}$ ) could constitute an easily recoverable substrate for the production of renewable energy through anaerobic digestion. 
Author Contributions: G.C.-T., L.A. and T.P. performed the experimental and laboratory work. G.C.-T., M.T., L.A., A.S.-C.-S., J.-M.F., Y.C. and T.P. worked on the analysis and interpretation of the data and contributed with valuable discussions. G.C.-T., M.T., L.A., A.S.-C.-S., J.-M.F., Y.C. and T.P. conceived the project, worked on the structure and wrote the paper. All authors have read and agreed to the published version of the manuscript.

Funding: This research was funded by Conseil Régional of Reunion Island. The funding body has no role in the design of the study and collection, analysis, and interpretation of data and in writing the manuscript.

Conflicts of Interest: The authors declare no conflict of interest.

\section{Appendix A}

Table A1. Eigenvalues obtained from PCA.

\begin{tabular}{cccccc}
\hline & $\mathbf{P C}_{\mathbf{1}}$ & $\mathbf{P C}_{\mathbf{2}}$ & $\mathbf{P C}_{\mathbf{3}}$ & $\mathbf{P C}_{\boldsymbol{4}}$ & $\mathbf{P C}_{\mathbf{5}}$ \\
\hline Eigen value & 2.28 & 1.31 & 0.69 & 0.49 & 0.23 \\
Variability (\%) & 45.62 & 26.23 & 13.81 & 9.72 & 4.61 \\
Cumulative variability (\%) & 45.62 & 71.85 & 85.66 & 95.39 & 100.00 \\
\hline
\end{tabular}

Table A2. Eigenvectors obtained from PCA.

\begin{tabular}{cccc}
\hline Parameters & PC $_{\mathbf{1}}$ & $\mathbf{P C}_{\mathbf{2}}$ & $\mathbf{P C}_{\mathbf{3}}$ \\
\hline Reduction of COD $(\%)$ & 0.509 & 0.351 & -0.281 \\
Effect on OD at 475 nm $(\%)$ & 0.457 & -0.516 & -0.021 \\
Reduction of minerals content $(\%)$ & 0.468 & -0.181 & 0.766 \\
Final pH & 0.250 & 0.754 & 0.234 \\
Biomass production $\left(\mathrm{g} \cdot \mathrm{L}^{-1}\right)$ & 0.501 & -0.094 & -0.528 \\
\hline
\end{tabular}

Table A3. PCA and HCA data related to the five original parameters.

\begin{tabular}{|c|c|c|c|c|c|c|}
\hline & & $\begin{array}{l}\text { Biomass } \\
\text { Production } \\
\left(\mathrm{g} \cdot \mathrm{L}^{-1}\right)\end{array}$ & $\begin{array}{l}\text { Reduction } \\
\text { of COD (\%) }\end{array}$ & $\begin{array}{l}\text { Reduction } \\
\text { of Minerals } \\
\text { Content ( } \%)\end{array}$ & Final $\mathrm{pH}$ & $\begin{array}{c}\text { Effect on OD at } \\
475 \mathrm{~nm}\end{array}$ \\
\hline \multirow{4}{*}{ All data } & Min. & 0.75 & 23.51 & 20.75 & 6.17 & 190.91 \\
\hline & Max. & 29.4 & 76.53 & 77.57 & 9.05 & 57.94 \\
\hline & Aver. & 15.85 & 57.5 & 45.07 & 8.02 & 105.24 \\
\hline & S.D. & 7.69 & 13.24 & 16.25 & 0.81 & 33.39 \\
\hline \multirow{4}{*}{ Cluster 1} & Min. & 19.77 & 65.98 & 39.05 & 7.79 & 110.14 \\
\hline & Max. & 29.4 & 76.53 & 77.57 & 9.05 & 42.46 \\
\hline & Aver. & 24.24 & 72.17 & 57.35 & 8.35 & 70.77 \\
\hline & S.D. & 3.3 & 3.1 & 18.36 & 0.54 & 16.13 \\
\hline \multirow{4}{*}{ Cluster 2} & Min. & 2.36 & 48.13 & 28.35 & 6.66 & 139.73 \\
\hline & Max. & 28.56 & 69.7 & 61.46 & 8.74 & 75.65 \\
\hline & Aver. & 15.94 & 59.38 & 44.55 & 8.02 & 104.13 \\
\hline & S.D. & 7.55 & 5.97 & 11.12 & 0.72 & 16.6 \\
\hline \multirow{4}{*}{ Cluster 3} & Min. & 0.75 & 40.91 & 20.75 & 7.54 & 190.91 \\
\hline & Max. & 15.21 & 62.09 & 49.05 & 9.03 & 130.64 \\
\hline & Aver. & 10.63 & 51.87 & 34.05 & 8.39 & 147.26 \\
\hline & S.D. & 4.17 & 6.46 & 10.26 & 0.45 & 18.83 \\
\hline \multirow{4}{*}{ Cluster 4} & Min. & 4.04 & 23.51 & 20.78 & 6.17 & 114.14 \\
\hline & Max. & 17 & 49.52 & 70.49 & 7.01 & 74.2 \\
\hline & Aver. & 9.30 & 34.87 & 43.83 & 6.57 & 92.8 \\
\hline & S.D. & 6.22 & 9.84 & 18.94 & 0.33 & 17.68 \\
\hline
\end{tabular}




\section{References}

1. GRFA Industry Issues. Available online: http://globalrfa.org/industry-issues/ (accessed on 11 February 2015).

2. UNICA and ApexBrasil Ethanol. Sugarcane Products. Available online: http://sugarcane.org/sugarcaneproducts/ethanol (accessed on 11 February 2015).

3. European Parliament and Council Directive. The Promotion of the USE of Energy from Renewable Sources and Amending and Subsequently Repealing Directives; 2009/28/EC, 2001/77/EC and 2003/30/EC; European Parliament and Council Directive: Strasbourg, France, 23 April 2009.

4. DAAF de la Réunion Présentation: Production, Superficies, Marché, Cadre Structurel ... . Available online: http://daaf.reunion.agriculture.gouv.fr/Presentation-production\#entete (accessed on 10 September 2020).

5. Patient, G.; Doligé, E. Le Renouvellement du Régime Fiscal Applicable au Rhum Traditionnel des Départements D'outre-mer. [The Renewal of the tax Regime Applicable to the Traditional Rum of the Overseas Departments.] (No. 754); French Senate: Pair, France, 2012.

6. Rajagopal, V.; Paramjit, S.M.; Suresh, K.P.; Yogeswar, S.; Nageshwar, R.D.V.K.; Avinash, N. Significance of vinasses waste management in agriculture and environmental quality-Review. Afr. J. Agric. Res. 2014, 9, 2862-2873. [CrossRef]

7. Hoarau, J.; Caro, Y.; Grondin, I.; Petit, T. Sugarcane vinasse processing: Toward a status shift from waste to valuable resource. A review. J. Water Process Eng. 2018, 24, 11-25. [CrossRef]

8. Rodrigues Reis, C.E.; Hu, B. Vinasse from sugarcane ethanol production: Better treatment or better utilization? Front. Energy Res. 2017, 5, 7. [CrossRef]

9. Arimi, M.; Zhang, Y.; Götz, G.; Kiriamiti, K.; Geißen, S.-U. Antimicrobial colorants in molasses distillery wastewater and their removal technologies. Int. Biodeterior. Biodegrad. 2014, 87, 34-43. [CrossRef]

10. Francisca Kalavathi, L.; Uma, L.; Subrumanian, G. Degradation and metabolization of the pigment-Melanoidin in distillery effluent by the marine cyanobacterium Oscillatoria boryana BDU 92181. Enzym. Microb. Technol. 2001, 29, 246-251. [CrossRef]

11. Hoarau, J.; Grondin, I.; Caro, Y.; Petit, T. Sugarcane distillery spent wash, a new resource for third-generation biodiesel production. Water 2018, 10, 1623. [CrossRef]

12. Martins, S.I.F.S.; Van Boekel, M.A.J.S. A kinetic model for the glucose/glycine Maillard reaction pathways. Food Chem. 2005, 90, 257-269. [CrossRef]

13. Rivero-Pérez, M.D.; Pérez-Magariño, S.; González-San José, M.L. Role of melanoidins in sweet wines. Anal. Chim. Acta 2002, 458, 169-175. [CrossRef]

14. González, T.; Terron, M.C.; Yagüe, S.; Zapico, E.; Galetti, G.C.; González, A.E. Pyrolysis/gas chromatography/mass spectrometry monitoring of fungal-biotreated distillery wastewater using Trametes sp. I-62 (CECT 20197). Rapid Commun. Mass Spectrom. 2000, 14, 1417-1424.

15. Godshall, M.A. Removal of colorants and polysaccharides and the quality of white sugar. In Proceedings of the Association Andrew Van Hook, Reims, France, 29 December 1992; pp. 28-35.

16. España-Gamboa, E.I.; Mijangos-Cortés, J.O.; Hernández-Zárate, G.; Maldonado, J.A.D.; Alzate-Gaviria, L.M. Methane production by treating vinasses from hydrous ethanol using a modified UASB reactor. Biotechnol. Biofuels 2012, 5, 82. [CrossRef] [PubMed]

17. Ferreira, L.F.R.; Aguiar, M.M.; Messias, T.G.; Pompeu, G.B.; Lopez, A.M.Q.; Silva, D.P.; Monteiro, R.T. Evaluation of sugar-cane vinasse treated with Pleurotus sajor-caju utilizing aquatic organisms as toxicological indicators. Ecotoxicol. Environ. Saf. 2011, 74, 132-137. [CrossRef] [PubMed]

18. Hoarau, J.; Petit, T.; Grondin, I.; Marty, A.; Caro, Y. Phosphate as a limiting factor for the improvement of single cell oil production from Yarrowia lipolytica MUCL 30108 grown on pre-treated distillery spent wash. J. Water Process Eng. 2020, 37, 101392. [CrossRef]

19. Tiwari, S.; Gaur, R.; Singh, R. Decolorization of a recalcitrant organic compound (Melanoidin) by a novel thermotolerant yeast, Candida tropicalis RG-9. BMC Biotechnol. 2012, 12, 30. [CrossRef] [PubMed]

20. Pant, D.; Adholeya, A. Biological approaches for treatment of distillery wastewater: A review. Bioresour. Technol. 2007, 98, 2321-2334. [CrossRef] [PubMed] 
21. Le Ministère Français de l'Ecologie, du Développement Durable et de l'Energie. Arrêté du 21 Juillet 2015 Relatif aux Systèmes D'assainissement Collectif et aux Installations D'assainissement non Collectif, à L'exception des Installations D'assainissement non Collectif Recevant une Charge Brute de Pollution Organique Inférieure ou Egale à 1,2 kg/j de DBO5; DEVL1519953N; The French Ministry of Ecology, Sustainable Development and Energy: Paris, France, 2015.

22. De Mattos, L.F.A.; Bastos, R.G. COD and nitrogen removal from sugarcane vinasse by heterotrophic green algae Desmodesmus sp. Desalin. Water Treat. 2016, 57, 9465-9473. [CrossRef]

23. Alaki, M.; Takahashi, T.; Ishiguro, K. Studies on microbiolofical treatment and utilization of cane molasses distillery wastes (Part 1): Screening of useful yeast strains. Bull. Fac. Agric. Mie Univ. 1981, 62, 155-161.

24. Kavanagh, K. Fungi-Biology and Applications; John Wiley \& Sons Ltd.: West Sussex, UK, 2011.

25. Sirianuntapiboon, S.; Somchai, P.; Ohmomo, S.; Atthasampunna, P. Screening of Filamentous Fungi Having the Ability to Decolorize Molasses Pigments. Agric. Biol. Chem. 1988, 52, 387-392.

26. Santal, A.R.; Singh, N. Biodegradation of Melanoidin from Distillery Effluent: Role of Microbes and Their Potential Enzymes. In Biodegradation of Hazardous and Special Products; Chamy, R., Ed.; IntechOpen: London, UK, 2013; pp. 71-104.

27. Rulli, M.M.; Villegas, L.B.; Colin, V.L. Treatment of sugarcane vinasse using an autochthonous fungus from the northwest of Argentina and its potential application in fertigation practices. J. Environ. Chem. Eng. 2020, 8, 104371. [CrossRef]

28. Del Gobbo, L.M.; Villegas, L.B.; Colin, V.L. The potential application of an autochthonous fungus from the northwest of Argentina for treatment of sugarcane vinasse. J. Hazard. Mater. 2019, 365, 820-826. [CrossRef]

29. Del Gobbo, L.M.; Colin, V.L. Fungal technology applied to distillery effluent treatment. In Approaches in Bioremediation. Nanotechnology in the Life Sciences; Prasad, R., Aranda, E., Eds.; Springer: Cham, Switzerland, 2018. [CrossRef]

30. Rolz, C.; Cabrera, S.; de Espinosa, R.; Maldonado, O.; Menchu, J.F. The growth of filamentous fungi on rum distilling slops. Ann. Technol. Agric. 1975, 24, 445-451.

31. De Lamo, P.; De Menezes, T.J. Bioconversao da vinhaca para a producao de biomassa fungica [Bioconversion of vinasse for the production of fungal biomass]. Coletânea Inst. Technol. Aliment. 1978, 9, 281-312.

32. Rosalem, P.; Tauk, S.; Santos, M.C. Efeito da temperatura, ph, tempo de cultivo e nutrientes no crescimento de fungos imperfeitos em vinhaca [Effects of temperature, $\mathrm{pH}$, cultivation time and nutrients in the growth of fungi imperfecti in vinasse]. Rev. Microbiol. 1985, 16, 299-304.

33. Araujo, N.; Visconti, A.; De Castro, H.; Barroso da Silva, H.; Ferraz, M.H.; Salles Filho, M. Producao de biomassa fungica de vinhoto [Fungal biomass production in vinasse]. Bras. Acucar. 1976, 88, 35-45.

34. Garcia, I.G.; Venceslada, J.L.B.; Peña, P.R.J.; Gómez, E.R. Biodegradation of phenol compounds in vinasse using Aspergillus terreus and Geotrichum candidum. Water Res. 1997, 31, 2005-2011. [CrossRef]

35. Chuppa-Tostain, G.; Hoarau, J.; Watson, M.; Adelard, L.; Shum Cheong Sing, A.; Caro, Y.; Grondin, I.; Bourven, I.; Francois, J.-M.; Girbal-Neuhauser, E.; et al. Production of Aspergillus niger biomass on sugarcane distillery wastewater: Physiological aspects and potential for biodiesel production. Fungal. Biol. Biotechnol. 2018, 5, 1. [CrossRef] [PubMed]

36. Kim, S.; Shoda, M. Decolorization of molasses and a dye by a newly isolated strain of the fungus Geotrichum candidum Dec 1. Biotechnol. Bioeng. 1999, 62, 114-119. [CrossRef]

37. Sluiter, A.; Hames, B.; Scarlata, C.; Sluiter, J.; Templeton, D. Determination of Ash in Biomass; No. NREL/TP-510-42622; National Renewable Energy Laboratory, U.S. Department of Energy: Golden, CO, USA, 2008.

38. Jollife, I.T. Principal Component Analysis, Springer Series in Statistics; Springer: New York, NY, USA, 2002.

39. Brown, C.E. Applied Multivariate Statistics in Geohydrology and Related Sciences; Springer: Berlin/Heidelberg, Germany, 1998.

40. Benito, G.G.; Miranda, M.P.; de los Santos, D.R. Decolorization of wastewater from an alcoholic fermentation process with Trametes Versicolor. Bioresour. Technol. 1997, 61, 33-37. [CrossRef]

41. Nudel, B.C.; Wahener, R.S.; Fraile, E.R.; Giuletti, A.M. The use of single and mixed cultures for aerobic treatment of cane sugar stillage and SCP production. Biogolical Wastes 1987, 22, 67-73. [CrossRef]

42. Kumar, V.; Wati, L.; Nigam, P.; Banat, I.M.; Yadav, B.S.; Singh, D.; Marchant, R. Decolorization and biodegradation of anaerobically digested sugarcane molasses spent wash effluent from biomethanation plants by white-rot fungi. Process Biochem. 1998, 33, 83-88. [CrossRef] 
43. Raghukumar, C.; Rivonkar, G. Decolorization of molasses spent wash by the white-rot fungus Flavodon flavus, isolated from a marine habitat. Appl. Microbiol. Biotechnol. 2001, 55, 510-514. [CrossRef] [PubMed]

44. Fahy, V.; Fitzgibbon, F.J.; McMullan, G.; Singh, D.; Marchant, R. Decolourisation of molasses spent wash by Phanerochaete chrysosporium. Biotechnol. Lett. 1997, 19, 97-99. [CrossRef]

45. Angayarkanni, J.; Palaniswamy, M.; Swaminathan, K. Biotreatment of Distillery Effluent Using Aspergillus niveus. Bull. Environ. Contam. Toxicol. 2003, 70, 268-277. [CrossRef]

46. Jiménez, A.M.; Borja, R.; Martin, A. Aerobic-anaerobic biodegradation of beet molasses alcoholic fermentation wastewater. Process Biochem. 2003, 38, 1275-1284. [CrossRef]

47. Miranda, M.P.; Benito, G.G.; Cristobal, N.S.; Nieto, C.H. Color elimination from molasses wastewater by Aspergillus niger. Bioresour. Technol. 1996, 57, 229-235. [CrossRef]

48. Mohammad, P.; Azamidokht, H.; Fatollah, M.; Mahboubeh, B. Application of response surface methodology for optimization of important parameters in decolorizing treated distillery wastewater using Aspergillus fumigatus UB2 60. Int. Biodeterior. Biodegrad. 2006, 57, 195-199. [CrossRef]

49. Ohmomo, S.; Kaneko, Y.; Sirianuntapiboon, S.; Somchai, P.; Atthasampunna, P.; Nakamura, I. Decolorization of Molasses Waste Water by a Thermophilic Strain, Aspergillus fumigatus G-2-6. Agric. Biol. Chem. 1987, 51, 3339-3346.

50. Shayegan, J.; Pazouki, M.; Afshari, A. Continuous decolorization of anaerobically digested distillery wastewater. Process Biochem. 2005, 40, 1323-1329. [CrossRef]

51. Patil, P.U.; Kapadnis, D.P.; Dhamankar, V.S. Decolorisation of synthetic melanoidin and biogas effluent by immobilised fungal isolate of Aspergillus niger UM2. Int. Sugar J. 2003, 105, 10-13.

52. FitzGibbon, F.; Singh, D.; McMullan, G.; Marchant, R. The effect of phenolic acids and molasses spent wash concentration on distillery wastewater remediation by fungi. Process Biochem. 1998, 33, 799-803. [CrossRef]

53. Sirianuntapiboon, S.; Sihanonth, P.; Somchai, P.; Atthasampunna, P.; Hayashida, S. An absorption mechanism for the decolorization of melanoidin by Rhizoctonia sp. D-90. Biosci. Biotechnol. Biochem. 1995, 59, 1185-1189. [CrossRef]

54. Seyis, I.; Subasioglu, T. Screening of different fungi for decolorization of molasses. Braz. J. Microbiol. 2009, 40, 61-65. [CrossRef] [PubMed]

55. Adikane, H.V.; Dange, M.N.; Selvakumari, K. Optimization of anaerobically digested distillery molasses spent wash decolorization using soil as inoculum in the absence of additional carbon and nitrogen source. Bioresour. Technol. 2006, 97, 2131-2135. [CrossRef]

56. Jiranuntipon, S.; Chareonpornwattana, S.; Damronglerd, S.; Albasi, C.; Delia, M.-L. Decolorization of synthetic melanoidins-containing wastewater by a bacterial consortium. J. Ind. Microbiol. Biotechnol. 2008, 35, 1313-1321. [CrossRef]

57. Ramezani, A.; Darzi, G.N.; Mohammadi, M. Removal of melanoidin from molasses spent wash using fly ash-clay adsorbents. Korean J. Chem. Eng. 2011, 24, 1035-1041. [CrossRef]

58. Hayase, F.; Kim, S.B.; Kato, H. Decolorization and degradation products of the melanoidins by hydrogen peroxide. Agric. Biol. Chem. 1984, 48, 2711-2717.

59. Mohana, S.; Desai, C.; Madamwar, D. Biodegradation and decolourization of anaerobically treated distillery spent wash by a novel bacterial consortium. Bioresour. Technol. 2007, 98, 333-339. [CrossRef]

60. Agarwal, R.; Lata, S.; Gupta, M.; Singh, P. Removal of melanoidin present in distillery effluent as a major colorant: A Review. J. Environ. Biol. 2010, 31, 521-528.

61. Tian, Z.; Mohan, G.R.; Ingram, L.; Pullammanappalil, P. Anaerobic digestion for treatment of stillage from cellulosic bioethanol production. Bioresour. Technol. 2013, 144, 387-395. [CrossRef]

62. Singh, H. Fungal treatment of distillery and brewery wastes. In Mycoremediation: Fungal Bioremediation; Wiley-Interscience: Hoboken, NJ, USA, 2006.

63. Tauk, S.M. Culture of Candida in vinasse and molasses: Effect of acid and salt addition on biomass and raw protein production. Eur. J. Appl. Microbiol. Biotechnol. 1982, 16, 223-227. [CrossRef]

64. Selim, M.H.; Elshafei, A.M.; El-Diwany, A.I. Production of single cell protein from yeast strains grown in Egyptian vinasse. Bioresour. Technol. 1991, 36, 157-160. [CrossRef]

65. Cajo, L.; Nizama, L.; Carreño, C. Effect of inoculum and molasses concentration as supplement to vinasse of distillery for the production of biomass of native Candida utilis. Sci. Agropecu. 2011, 65-72. [CrossRef]

66. Bushell, M.E. Chemical requirements for growth. In Fungal Physiology, 2nd ed.; Wiley \& Sons, Inc.: New York, NY, USA, 1994; pp. 130-157. 
67. Kavanagh, K. Introduction to fungal physiology. In Fungi-Biology and Applications; West Sussex: London, UK, 2011; pp. 1-34.

68. Cattell, R.B. The scree test for the number of factors. In A History of Psychology in Autobiography; Lindzey, G., Ed.; Prentice-Hall, Inc.: Englewood Cliffs, NJ, USA, 1974; Volume VI, pp. 61-100.

Publisher's Note: MDPI stays neutral with regard to jurisdictional claims in published maps and institutional affiliations.

(C) 2020 by the authors. Licensee MDPI, Basel, Switzerland. This article is an open access article distributed under the terms and conditions of the Creative Commons Attribution (CC BY) license (http://creativecommons.org/licenses/by/4.0/). 